\title{
Cleaner Technology and Sustainable Development: Contributions of Brazilian Clean Development Mechanism (CDM) Projects
}

\author{
Antônio Costa Silva Júnior, José Célio Silveira Andrade \\ Federal University of Bahia, Salvador, Brazil
}

\begin{abstract}
Brazil is the world's third most successful bidder for CDM projects, only behind China and India. One of the main objectives of CDM is to promote sustainable development in the developing countries through the transfer of environmentally sound technologies. Assuming that the generation of cleaner technologies is the most effective strategy for achieving this CDM goal, this paper was built upon the following research question: Is CDM effective in promoting sustainable development and the generation of cleaner technologies in Brazil? Thus, this paper evaluates the contribution of $10 \mathrm{CDM}$ projects for the generation of cleaner technologies and the promotion of sustainable development in Brazil. For this, 10 cases that represent the Brazilian CDM context were selected out of 75 PDDs (Project Design Documents) approved by September 2009: five renewable energy production projects and five other on swine/urban waste treatment and $\mathrm{N}_{2} \mathrm{O}$ destruction. A multiple-case study method was chosen and a data triangulation technique was used to collect the data from the 10 selected projects. The analysis and discussion of results was made based on a model built upon the following concepts: CDM project cycle, technology transfer, environmental technology and sustainable development. The results of this study demonstrate the prevalence of projects that: (1) use end-of-pipe technologies; (2) have a single or double bottom line profile with regard to sustainable development; and (3) show endogenous technology transfer, with the acquisition/development of most of the know-how and equipment in Brazil. In short, this paper defends Brazilian CDM projects which make only a modest contribution to cleaner technology generation and to the promotion of triple bottom line sustainable development.
\end{abstract}

Keywords: cleaner technology, sustainable development, clean development mechanism (CDM), Brazil

\section{Introduction}

The increase in Greenhouse Gas (GHG) ${ }^{1}$ emissions into the Earth's atmosphere is changing temperatures to figures higher than those expected within the natural variations that have always affected the climate, causing

Antônio Costa Silva Júnior, Ph.D. in Industrial Engineering, Research Associate, World Political Analysis Laboratory (LABMUNDO) Department, Federal University of Bahia.

José Célio Silveira Andrade, Ph.D. in Administration, Professor, World Political Analysis Laboratory (LABMUNDO) Department, Federal University of Bahia.

Correspondence concerning this article should be addressed to José Célio Silveira Andrade, Avenida Reitor Miguel Calmon s/n Vale do Canela Salvador Bahia Brazil CEP 41100903. E-mail: celiosa@ufba.br.

${ }^{1}$ Gases such as: carbon dioxide $\left(\mathrm{CO}_{2}\right)$, methane $\left(\mathrm{CH}_{4}\right)$, nitrous oxide $\left(\mathrm{N}_{2} \mathrm{O}\right)$ and hydrofluorocarbons (HFCs). They have different Global Warming Potentials (GWP) which is measured relative to the warming potential of $\mathrm{CO}_{2}$. Thus, for example, the GWP of $\mathrm{CH}_{4}$ is 23 tonnes of $\mathrm{CO}_{2}$ equivalent per tonne of $\mathrm{CH}_{4}$, and the GWP of $\mathrm{N}_{2} \mathrm{O}$ is 296 tonnes $\mathrm{CO}_{2}$ eq/tonnes $\mathrm{N}_{2} \mathrm{O}$. 
so-called "global warming". In 1988, the World Meteorological Organization (MWO) and the United Nations Environment Program (UNEP) established the Intergovernmental Panel on Climate Change (IPCC) in order to gather the world's leading climate scientists to research the possible effects of climate evolution in an international scale (Grau-Neto, 2007).

Using the IPCC's evaluations during the 3rd Conference of the Parties (COP-3), in 1997 the international community created the Kyoto Protocol, a multilateral agreement that defines specific targets for GHG emission reduction for developed countries, members of Annex I.

To ensure compliance with the commitments of the Climate Change Convention, adopted at Rio-92, this protocol provides three flexibile mechanisms: Joint Implementation (JI), which allows industrialized countries to offset their emissions by funding GHG reduction projects in other industrialized countries; Emissions Trading (ET), which allows countries to share their allowed emissions; and the Clean Development Mechanism (CDM), which allows industrialized countries to achieve their individual reduction goals of emissions through projects implemented in developing countries. CDM is especially important on the world stage as it is the only one that allows developing countries (no-Annex I) to participate through funding from member countries of Annex I. It is noteworthy that developing countries still do not have targets for the first commitment period of the Kyoto Protocol which ends in 2012 (Ventura, 2008; Goldemberg, 2005).

For the activities proposed in CDM projects to be eligible, certain criteria must be fulfilled, including that of “additionality”, which requires proof of actual GHG emissions reduction, which, otherwise, would not occur in the absence of the project, and also its contribution to the sustainable development of the country where it was implemented through the transfer of environmentally sound technologies. These criteria were defined with an attempt not only to ensure the involvement of developing countries in the minimization of global climate change effects, whose main culprits are the industrialized countries, but also to make a new development model possible (Lopes, 2002).

In December 2009 the COP-15 took place in Copenhagen and aimed to settle post-Kyoto rules. Among other countries, the USA, China and Brazil waived GHG reduction targets for 2020 . The USA pledged a $17 \%$ cut in GHG emissions from 2005 levels, through changes in regulation of various industries, including car production. China announced they would be reducing about $40 \%$ to $45 \%$ (ANDI, 2009).

At this conference Brazil committed itself to reducing GHG emissions between 36.1\% and 38.9\%. In order to highlight the seriousness of this commitment, the Brazilian Senate approved a bill to create a National Policy on Climate Change, which turned its voluntary emissions reduction proposal into a legal obligation to be fulfilled by the country's future governments (Brazil, 2009). Even with two superpowers waiving reduction targets and Brazil settling for ambitious reduction goals, the COP-15 did not reach its main objective- to define a new regulatory milestone under international law to fight global warming in the post-Kyoto period. Its only achievement was the Copenhagen Agreement, a letter of intent from the 192 participating nations to maintain the global temperature increase within a maximum 2 degrees but without establishing global targets for reducing GHG emissions by 2020 (Abranches, 2009).

Thus, considering that one of the main objectives of CDM is to promote sustainable development in non-Annex I countries through the transfer of environmentally sound technologies, and assuming that the generation of cleaner technologies is the most effective strategy for achieving this goal, this paper was built upon 
the following research problem: Is CDM effective in promoting sustainable development and the generation of cleaner technologies in Brazil?

This analysis is especially important when considering that today Brazil is the world's third most successful bidder for CDM projects (6\%), only behind China (39\%) and India (27\%) (UNFCCC, 2011). By June 2011 there were $499 \mathrm{CDM}$ projects approved in Brazil, of which 67\% aimed at reducing $\mathrm{CO}_{2}, 32 \% \mathrm{CH}_{4}, 1 \% \mathrm{~N}_{2} \mathrm{O}$ and $0.4 \%$ PFCs. These projects focus on the fields of renewable energy (52.3\%), swine manure treatment systems (15.4\%) and fossil fuel substitution (9.2\%). The Brazilian regions with the largest number of CDM projects are the Southeast, South and Midwest, with 37\%, 26\% and 16\% respectively. The remaining 21\% share is distributed between the Northeast and North Brazil. As for the Annex I countries which buy most of the carbon credits from CDM projects developed in Brazil, these include the United Kingdom, Switzerland, Netherlands, New Zealand and Japan. With the exception of Switzerland, these countries are either islands or located in areas below sea level—vulnerabilities that may justify their particular interest in funding this type of projects (MCT, 2011).

This paper focuses on evaluating the contribution of CDM projects to sustainable development and cleaner technologies in Brazil. As little has been written on this topic to date, this paper expects to fill a gap in CDM studies from the international and Brazilian scientific community. It should be noted that the approaches of papers presented recently at the Academy of Management Annual Meeting on climate change are diverse and mainly focused on the experience and reality of developed countries: the inclusion of climatic aspects in the strategic environment of businesses (Haigh, 2009); the relationship between GHG emissions and market performance (Russo \& Pogutz, 2009); climate change risk and opportunity analysis for banking institutions (Furrer, 2009).

Few studies are meant to assess the effectiveness of CDM projects for sustainable development and the generation of cleaner technologies in the main host countries, such as Brazil, thereby justifying this paper's purpose. Among such studies, the preliminary research done by Silva-Junior, Napravnik-Filho, and Andrade (2009) and Andrade, Silva-Junior, Napravnik Filho, Telesforo, and Ventura (2009) should be pointed out. They examined 75 PDDs (Project Design Documents) out of the 221 CDM projects approved in Brazil by September 2009 and argue that the contribution of CDMs to cleaner technologies and sustainable development promotion in such country remains modest, despite the large number of projects.

Hence, considering that the aforementioned Brazilian studies only used document analysis, this paper aims to analyze the contribution of $10 \mathrm{CDM}$ projects in Brazil in terms of sustainable development and cleaner technology promotion in greater depth. To achieve this goal, a multiple-case study was carried out. This paper is structured in three parts, besides the introduction and conclusion, the first part presents the literature overview, the second describes the methods adopted, and the third part presents the analysis and results.

\section{Literature Overview}

In order to construct the research analysis model used in this paper, the literature overview is presented: the description of CDM project cycle; a discussion on environmentally sound technology transfer to CDM host countries; the analysis of two types of environmental technologies: end-of-pipe versus cleaner technologies; and, finally, the discussion of triple bottom line sustainable development concept. 


\section{CDM Project Cycle}

A CDM project cycle involves very specific steps following a rationale similar to that of management systems certification according to normative models from the International Organization for Standardization (ISO). Thus, different actors have very important roles, being responsible for approval instances which grant credibility to the carbon credit certification process (Seiffert, 2009).

According to MCT (2008), for projects to be approved by the CDM Executive Board (CDMEB) resulting in Certified Emission Reductions (CERs) their activities must necessarily pass through the seven stages of the project cycle, namely: (1) PDD preparation; (2) validation by a Designated Operational Entity (DOE), checking whether the project complies with the rules of the Kyoto Protocol; (3) approval by the Designated National Authority (DNA) in Brazil represented by the Interministerial Commission on Global Climate Change (CIMGC). One of the main aspects of this stage is verifying if the project will contribute to the country's sustainable development; (4) submission to the Executive Council coordinated by the United Nations Framework Convention on Climate Change (UNFCCC) for project registration. The registration acts as formal recognition by the UN of the contribution of the CDM project activities to minimize climate change; (5) monitoring-deals with gathering and storing all the data needed to calculate the GHG emissions reductions, according to the baseline methodology established in the PDD; (6) verification/certification-periodic and independent audit process for reviewing calculations of GHG emissions reduction; and (7) CER issuance in accordance with each project. In this step, the CDMEB ensures that by fulfilling all the steps, the GHG emissions reduction resulting from project activities are real, measurable, and long-term ones and, therefore, they can originate CERs.

It is in the first step of this cycle (during the PDD preparation) that project proponents must describe the activity implemented, list all the participants involved, detail the methodology and baseline adopted, report GHG reduction and draw up the monitoring plan that will be used. It is also here that applicants must describe the factors considered critical for the approval of the CDM project-the project's contributions to sustainable development and the roles played by stakeholders. Thus, information provided by the project's applicant organization in the PDD is essential for verification matters, both by the DNA and the CDMEB, with regard to the project's eligibility (Lopes, 2002). This author stated that in addition to the criterion of additionality, a basic condition for CDM project approval is proof that the views of all stakeholders-including individuals, groups and communities - were considered during the preparation of PDDs. This position reflects the perception of Esty and Winston (2006) that nowadays there is a growing concern among businesses with the amount of attention directed towards various stakeholders, such as Non-Governmental Organizations (NGOs) and community-based organizations. CDM projects should take into account the opinions of all its stakeholders in order to map their influence.

Within the CDM projects' PDDs, applicant organizations also provide information on: the influence of public policies for project funding; the motivations that led them to propose the project; and the main barriers that can affect project development. Seiffert (2009) states that all PDDs should also take into consideration the CDM contributions to the promotion of sustainable development focusing on the triple bottom line: social, environmental and economic.

Finally, for Vela and Ferreira (2005), applying for a CDM project involves high transaction costs as well as risks and uncertainties, all of which represent possible barriers to project execution in Brazil and other developing 
countries. These authors mention funds established for carbon credit purchase and sale, such as the Carbon Facility, and the use of public funding policies as possible options for minimizing costs, risks and uncertainties. According to Telesforo and Loyola (2009), government support, not only in the form of funding but also in the form of public policies that promote CDM, is essential for the development of these projects in Brazil. Such public policies would also encourage the promotion of cleaner technologies in the host countries of CDM projects such as Brazil, as discussed in the section below.

\section{Technology Transfer}

Another action that is being made in relation to the carbon credit market is the creation of the Voluntary Markets. These markets are formed by groups or sectors that have no obligations as to reduce their emissions or by companies located in countries not signatories to the Kyoto Protocol as the United States.

The technology transfer issue is increasingly gaining importance, both in the political and academic fields (Bozeman, 2000). The exogenous technology transfer issue has been present for a long time on the global environmental agenda, playing a central role in North-South ecopolitics. It usually carries the idea of knowledge transfer from the more developed countries (Northern hemisphere countries) to the least developed countries (Southern hemisphere countries). It is believed that countries with already established knowledge and expertise in environmentally sound technologies should transfer them to countries with little or no installed technological capacity in order to decrease the gap that exists between North and South in terms of technology matters (Esty \& Ivanova, 2002; Le Prestre, 2005).

Hence, the Kyoto Protocol intends to incentive the exogenous technology transfer process, specifically from developed nations to developing ones, because only non-Annex I countries can participate as hosts of CDM projects that, later on, generate CERs, which are then acquired by Annex I nations. Schneider, Holzer, and Hoffman (2008) note that exogenous technology transfer is strategic for promotion of environmentally sound technologies and sustainable development in the CDM host countries. However, Rosemberg (2006) highlights that exogenous transfers of technology depend heavily on specific local circumstances and need great levels of technical skills and expertise from the host countries.

Analyzing Article 10 of the Kyoto Protocol, it is observed that exogenous technology transfer is part of this international public policy's scope, as the Parties shall cooperate to "promote the transfer of know-how pertinent to climate change, in particular to developing countries, including the formulation of policies for the effective transfer of environmentally sound technologies” (Brazil, 2004, p. 27).

Then, taken into consideration the Seres' (2007, pp. 2-3) definition of technology transfer as: "a set of processes covering the flows of know-how, experience and equipment for mitigating the climate change amongst different stakeholders such as governments, private sector, financial and research institutions and NGOs”, this paper argues that technology transfer in CDM projects can occur according to the following terms (Tigre, 2006; Kanai, 2008; Radosevic, 1999; Dechezleprêtre, Glachant, \& Méniére, 2009): (1) technology transfer contracts, licenses and patents, partnerships with universities, research centers, government agencies, strategic alliances, joint ventures, subcontracting for development of local machinery and equipment suppliers; (2) technologies incorporated in imported machinery, equipment and software; (3) know-how registered in operations manuals, software applications, courses and practical training programs; (4) tacit knowledge acquired through consulting, 
technical support and qualification processes; (5) cumulative learning: the process of change and improvement of technologies by the host countries through learning by doing; and (6) technological self-development: Research, Development and Innovation (R, D \& I) efforts, reverse engineering and experimentation in the host countries.

Due to that, this paper considers that the transfer of technology can be exogenous, endogenous or both. Technology transfer is classified as exogenous in cases where the process occurs from Annex I countries to non-Annex I nations. Technology transfer is endogenous when the technology is developed from within a non-Annex I country such as Brazil, and is domestically replicated among productive sectors, regions and states of these countries (Zhao \& Reisman, 1992; Kanai, 2008).

Ellis, Winkler, Corfee-Morlot, and Cagnon-Lebrun (2007), Blackman (1999) and Rosemberg (2006) argue that in the development of CDM projects there is preference for host countries that have: good opportunities for implementing projects that reduce GHG emissions; advanced technological development; human capital and infrastructure; and, especially, relatively advanced environmental policies. This would explain, for example, why there are so many existing CDM projects in India, China and Brazil. These ideas can be supported by the results reported by Seres (2007, p. 4), which state that "host countries can influence the extent of technology transfer involved in its CDM projects".

So the analysis of technology transfer in CDM projects should therefore consider the asymmetries that exist among non-Annex I countries, especially regarding training capacity and technological development, which differ greatly from country to country. Specifically in the Brazilian context, where there are consolidated cleaner technological capabilities in fields such as renewable energy, biofuels and biomass, the idea of transferring environmentally sound technologies through CDM projects is losing its meaning and may end up favoring the old development models focused on importation of environmentally outdated end-of-pipe technologies. This kind of environmental technology contributes little to the clean development of countries that host CDM projects as they focus on remediating negative environmental impacts and not on eco-efficiency of natural resources, as discussed in the section below.

\section{Environmental Technologies: End-of-Pipe Versus Cleaner Technology}

Environmental technologies can be divided into end-of-pipe pollution control technologies and cleaner technologies. The former do not entail changing the production system, but rather introducing additional technological systems that capture pollutants in order to reduce their negative impact on the environment. Cleaner technologies, on the other hand, do not seek to treat pollution after it has been produced. They actually seek to avoid or reduce such emissions in advance, dealing with the causes of environmental degradation and not with its consequences. Cleaner technologies are based on the principle of prevention, while the end-of-pipe technology, which conceptually is also considered environmentally sound, is guided by the principle of correction (Lenzi, 2006).

For the WBCSD (2006), the use of cleaner technologies can be understood as the continuous application of a technical, economic and environmental strategy integrated into processes, products and services, for increasing efficiency in raw materials, water and energy usage. Cleaner technologies are characterized by the adoption of strategies to reduce or eliminate at source the production of any pollution, while rationalizing the usage of natural resources (eco-efficiency principle). Thus, the 3R concept is reinforced: reduce, reuse, and recycle. 
The presentation order of the aforementioned 3Rs is not random because the more the practices of cleaner production tend to reduce waste, the more they are related to reduction at source and to relevant changes in the core of production processes. The more these practices relate to waste treatment from production processes, the more they will tend to be end-of-pipe practices (LaGrega, Buckingham, \& Evans, 1994).

In the pursuit of waste reduction at source, CDM projects would tend to innovate in production processes through loss elimination, not only reducing environmental impacts, but also production costs. Therefore, the diffusion of innovative environmental strategies in CDM projects would lead to a greater use of cleaner technologies, leading to a double dividend, in which businesses would become more competitive and society as a whole would benefit from the reduction of environmental impacts caused by GHG emissions (Kiperstok, 2003).

According to studies by Schneider, Holzer, and Hoffman (2008), CDM projects that focus on end-of-pipe technology, such as burning biogas generated in landfills and in swine manure treatment systems, present fewer technology transfer related risks than projects that promote cleaner production practices, because while the former use off-the-shelf equipment and knowledge already mastered, the latter require extra R, D \& I efforts for their development. According to Pearson (2007), as of now, projects that promote cleaner production practices such as wind farms have no significant carbon credit price differentiation and generate small amounts of carbon credits, while projects such as landfills generate high amounts of carbon credits, due to an end-of-pipe biogas burning practice, while doing very little for the sustainable development of non-Annex I host countries. This viewpoint is endorsed by Wilkins (2002) who also notices the higher financial risk of CDM projects that promote technological innovation to support cleaner production practices.

Thus, this paper highlights the importance of developing cleaner technologies, instead of developing CDM projects that solely promote end-of-pipe practices. This paper supports, therefore, that promoting cleaner technologies is the most effective strategy to be used by Brazilian CDM projects to contribute to the country's sustainable development, as discussed in the section below.

\section{Sustainable Development and Triple Bottom Line}

Defined as "meeting the needs of the present without compromising the ability of future generations to meet their needs", the sustainable development concept—set by Brundlant Comission (1987, p. 15)—is in constant evolution. However, three basic components—social, economic and environmental, also known as the triple bottom line-are constantly mentioned in literature that deals with sustainable development.

According to Elkington (1994), the triple bottom line represent the main features of this development model: quality of life and social equity improvement, representing the social goals of the model; efficiency and growth, necessary but not sufficient economic goals for the model; and environmental conservation, considered a prerequisite for long-term sustainability.

However, although the components of the triple bottom line are recurrent in sustainable development literature, some authors argue that the number should be higher than three: Sachs (1993) suggests five- -social, economic, ecological, spatial and cultural—Guimaraes (2001) recommends seven—ecological, environmental, demographic, cultural, social, political and institutional, and so on. Even when the sustainable development model is open to a greater range of components and is used with different meanings by the most diverse segments of society, it is important to note that, as Milani and Keraguel (2007) stated, there is some consensus over this 
development model being anchored to the balance between environmental, social and economic spheres, although the relationship between the present and future generations can also be taken into consideration.

For the scope of this paper, which aims among its objectives to assess the contribution of Brazilian CDM projects for the country's sustainable development-the original triple bottom line standard was used, as established in the Brundlant Report and adherent to the principles of the Kyoto Protocol regulatory framework. It is important to emphasize that the search for sustainable development is not a harmonic process void of conflicts of interests, but a process of change in development models, through which the exploitation of environmental resources, investment choices, directions of technological innovations and new institutional frameworks must remain in accordance to the needs of current and future generations (Soares-Neto, 2004).

The sustainable development concept was not forgotten in the formulation of the Kyoto Protocol. This assertion can be clearly demonstrated within the context of CDM projects-Article 12.1 of the Protocol states that the goal of these projects is to "assist Parties not included in Annex I in achieving sustainable development [...] contributing to the ultimate objective of the Climate Change Convention” (Brazil, 2004, p. 28). On normative matters, the commitment to promoting sustainable development in host countries is a required step in the CDM project cycle, as discussed earlier, making the triple bottom line a variable to be considered when evaluating the eligibility of these projects.

Nevertheless, the Kyoto Protocol does not clearly state what criteria should be observed by each host country to assess the degree of contribution of CDM projects to sustainable development. Each country defines the criteria to be used through its DNA. The Brazilian DNA, CIMGC (2003), thus defined a set of five criteria as basic prerequisites for evaluating the contribution of CDM projects to the country's sustainable development: (1) contribution to local environmental sustainability-assesses the local environmental impacts mitigation (solid waste, wastewater, air pollutants, among others) provided by the CDM project in comparison to "baseline scenario" estimates where no CDM project exists; (2) contribution to the development of working conditions and net employment generation — evaluates the project's commitment to social and labor issues, to health and education programs, and to civil rights. It also evaluates job creation, compared to the "baseline scenario"; (3) contribution to income distribution — analyzes the effects on the quality of life of low-income populations, noting the socio-economic benefits brought by the project; (4) contribution to technological development and training - this assesses the project's degree of technological innovation, in relation to both the "baseline scenario" and the type of environmental technology employed; and (5) contribution to regional integration and linkages with other sectors - this measures how well the project integrates with other socioeconomic activities in its deployment region.

Note that it is beyond the scope of this paper to discuss the prerequisites established by CIMGC in detail. These prerequisites were taken into consideration within the domain of the environmental, economic and social components of the triple bottom line used as the standards for evaluating the contribution of the studied Brazilian CDM projects to the country's sustainable development.

\section{Methods}

Based on the main concepts presented in the literature overview, a research analysis model was built (see Table 1). This model shows the theoretical constructs, the analytical dimensions and the components used to 
assess the CDM projects. It was used as the basis to execute the data collection and support the analysis and discussion of results (Quivy \& Campenhoudt, 1998).

Table1

Research Analysis Model

\begin{tabular}{|l|l|l|}
\hline Concept & Dimension & Component \\
\hline \multirow{2}{*}{ CDM Project } & \multirow{2}{*}{ Technology } & Main Barriers and Motivations \\
\cline { 2 - 3 } & & Public Policies Influence and Role of Stakeholders \\
\hline Sustainable Development & Technology Transfer & Type and Form \\
\cline { 2 - 3 } & Environmental Technology & Type and Strategy \\
\hline
\end{tabular}

The qualitative multiple-case study method was adopted to investigate the $10 \mathrm{CDM}$ projects, because it allows taking into consideration their particular meanings and contexts (Yin, 2001). The research strategy was designed in three parts: selecting ten cases; collecting secondary (bibliographic and documentary) and primary (interviews and field research) data; analyzing and discussing results.

The 10 projects studied in this paper were selected out of 75 projects that had their PDDs previously analyzed by Silva-Junior et al. (2009) and Andrade et al. (2009). Table 2 presents the 10-case sample in this paper, classified by activity categories, GHG emissions reduction figures and amount of energy generated. This sample represents the Brazilian context: five renewable energy production projects, which represent nearly $50 \%$ of all Brazilian CDM projects, and five other on swine/urban waste treatment and $\mathrm{N}_{2} \mathrm{O}$ destruction, which mostly cover the remaining 50\% of CDM projects approved in Brazil.

Table 2

Research Sample

\begin{tabular}{|c|c|c|c|c|}
\hline Project category & Amount & Name & $\begin{array}{l}\text { GHG reduction } \\
\text { (tons } \mathrm{CO}_{2} \text { eq/year) }\end{array}$ & $\begin{array}{l}\text { Energy produced } \\
\text { (MW/year) }\end{array}$ \\
\hline $\begin{array}{l}\text { Hydroelectric and other } \\
\text { renewables (wind and biomass) }\end{array}$ & 5 & $\begin{array}{l}\text { Grupo Votorantim, Erval Seco, Rosa } \\
\text { dos Ventos, Água Doce e Lages }\end{array}$ & 335.571 & 622.015 \\
\hline $\begin{array}{l}\text { Swine waste, landfills and } \\
\text { destruction of } \mathrm{N}_{2} \mathrm{O}\end{array}$ & 5 & $\begin{array}{l}\text { Sadia, Agrosuinos/Agcert, Vega, } \\
\text { Nova Gerar e Fafen/Petrobras }\end{array}$ & $1,894,712$ & 102.24 \\
\hline Total & 10 & & $2,230,283$ & 724.255 \\
\hline
\end{tabular}

Secondary data collected from the PDDs of these 10 projects were supplemented with information obtained from institutional documents and websites of the proponents. Primary data were obtained by conducting semi-structured interviews with project managers and by doing technical visits to sites of the studied projects. All the data were compared using a data triangulation technique proposed by Kopinak (1999) and processed using a qualitative approach to content analysis (Bardin, 1977), aiming to analyse and discuss the results.

\section{Analysis and Results}

In this part, descriptions and analysis of all the ten cases are presented and subsequently, a comparative analysis and discussion of the results is shown based on the research analysis model.

\section{Case Presentation}

Two institutions highlight in the CCS research and development in Brazil are the Center for Research and Development Leopoldo Américo Miguez de Mello/Petrobras (CENPES) and the Center for Excellence in 
Research on Carbon Storage/PUC-RS (CEPAC). For the capture of $\mathrm{CO}_{2}$ is worth mentioning also the research activities conducted by the University of Salvador (UNIFACS).

\section{Rosa dos Ventos}

Rosa dos Ventos (2007) is an independent power producer, which has been operating since 2008 with two wind power projects in northeastern Brazil, with total installed capacity of $13.73 \mathrm{MW}$. Its CDM project provides a reduction of 17,814 tons of $\mathrm{CO}_{2}$ eq/year between 2008 and 2014, by generating 66,600 MW/year of energy contracted under PROINFA (a public funding policy designed to promote renewable energy sources in Brazil launched in 2004).

The main barriers faced by Rosa dos Ventos were: too much bureaucracy and lack of clear rules from PROINFA regarding carbon credits revenue distribution; high risks for project implementation for being a pioneering initiative; the absence of qualified Brazilian suppliers; and the local community's resistance, who saw the project as a threat to the sustainability of the region's nationally recognized tourist industry. The economic incentive provided by carbon market was the main factor in the project feasibility. However, no profit has been generated because no resources have been received from the sale of carbon credits, due to PROINFA's lack of clear rules on what to do with carbon credit revenue (A. Lima, personal communication, November 24, 2009).

The transfer of exogenous technology is evident, of both equipment and know-how, mainly from India. However, as PROINFA demanded that at least $60 \%$ of the project be nationalized, it was also necessary to develop Brazilian suppliers for machines and accessories. Aspects such as professional training, job creation and income generation for the local community and the development of domestic suppliers were derived from the cleaner technology that was produced. These are considered social and economic benefits directly derived from the CDM project, as it contributes to local sustainable development. The environmental programs developed by the project to strengthen the relationship with local communities and other stakeholders are also noteworthy: planting native vegetation and constructing access roads with minimal environmental impact (Rosa dos Ventos, 2007).

\section{Água Doce}

Like Rosa dos Ventos this project was executed under the PROINFA in South Brazil. It is under the responsibility of a private company called Central Nacional de Energia Eólica and produces 26,063 MW/year of wind power. It began operating in 2004 and predicted a reduction of 13,704 tonnes of $\mathrm{CO}_{2}$ eq/year (Água Doce, 2006).

As in the Rosa dos Ventos case, the main challenges were: the lack of clear rules from PROINFA regarding carbon credit revenues distribution; the risks inherent in being a pioneering initiative; the absence of Brazilian qualified machinery and equipment suppliers; and the lack of power lines in the region for distributing wind power. Among the main motivators, the greatest were: the development of cleaner energy sources in Brazil; the growing demand for energy in the country; and, the business profitability opportunity only made possible by entering the carbon market (M. Junqueira, personal communication, July 23, 2009).

In this project, the exogenous transfer of technology is evident both in terms of equipment and know-how, imported from Germany. Unlike the Rosa dos Ventos case, the Agua Doce project is a classic example of exogenous transfer of technology from a developed country to a developing nation, as established by the Kyoto 
Protocol. The social benefits were: professional training and job creation and income generation; tightening the relationship between the project and the local community, especially as it has become a tourist attraction in the region. Environmentally, the project did reforestation of native vegetation, monitored the local fauna and flora, reduced GHG emissions and promoted cleaner energy in Brazil. As for the economic component, it enabled the purchase of some equipment from the domestic market generating tax revenue, stimulating employment and income generation and strengthening local economic growth.

\section{Grupo Votorantim: Pedra do Cavalo Hydroelectric Power Plant (UHEPC)}

Unlike the first two projects presented, the UHEPC project was developed by a Brazilian holding company with international operations, Grupo Votorantim. In Brazil the group represents one of the largest private industrial conglomerates in the fields of steel and cement. Located in Northeast Brazil, this CDM project foresees a reduction of 59,485 tonnes of $\mathrm{CO}_{2}$ eq/year. It consists of a hydroelectric plant whose dam, reservoir and flooded area have pre-existed since the 1980s. Electrical substations and two $160 \mathrm{MW}$ turbines were installed, producing an average of 494,064 MW/year (Grupo Votorantim, 2006).

The biggest barriers to project implementation consisted of excessive bureaucracy to obtain funding from the BNDES (a public development bank in Brazil) and the resistance of communities living near the dam. Among the existing motivations for project execution, the Grupo Votorantim highlights: diversifying the holding's business units by adding energy production as a new business; aiding the energy crisis that struck Brazil in 2001; and generating business profitability, mainly for providing cheap energy for their own cement and steel industries (E. Carvalho, personal communication, August 2, 2009).

The exogenous transfer of technology was very little, only evident in secondary equipment purchased in Germany. Much of the machinery and know-how required for project development were acquired on the domestic market. Thus, technology transfer was mainly endogenous due to Brazil's mastery in hydroelectric technology production - $70 \%$ of the Brazilian energy matrix comes from hydroelectric energy sources. Socially, the UHEPC project has generated employment, improved the public infrastructure of adjacent municipalities and provided professional training for plant operation and maintenance. Environmentally, besides GHG emissions reduction, the project has contributed to the reforestation of riparian vegetation and the conservation of flora and fauna in its area of influence. Economically, the project purchased most of the equipment and know-how in Brazil, contributing to the national economy, as well as generating tax revenues (Grupo Votorantim, 2006).

\section{Erval Seco Small Hydroelectric Plant-Erval Seco SHP}

BT Geradora de Energia Elétrica S.A. is the Brazilian company responsible for operating the Erval Seco SHP located in South Brazil. This project, approved in 2002, foresees a 24,129 tonnes of $\mathrm{CO}_{2}$ eq/year reduction and is capable of generating 34,976 MW/year, thereby avoiding the importation of non-renewable energy from other regions of Brazil, such as oil-based thermal power plant energy (BT Geradora de Energia Elétrica (PCH), 2005).

In this project, the main barriers faced were the lack of public funding policies for renewable energy in Brazil back then, and the veto of public funding request to regional development banks, because the investment risk was considered too high. The main motivators for the company to invest in the project were aiding the energy crisis experienced by Brazil in 2001, the growing demand for energy from renewable sources, and especially the 
opportunity of new business profitability through the carbon market (W. Back, personal communication, July 16, 2009).

As in the Grupo Votorantim case, the transfer of technology was predominantly endogenous as Brazil has already mastered hydroelectric plant technology. Since it is a SHP construction project with little environmental impact and using a renewable energy source, the technology employed in this project is considered cleaner. It should also be noted that the operation of SHPs in small isolated towns avoids the use of thermal power plants which use non-renewable resources to generate electricity. It was observed that this project contributed to the sustainable development of its area and influence it considerably. Socially, the power plant has become a leisure destination for the local community and has promoted family farming, contributing to the generation of employment and income and establishing people in rural areas. Environmentally, the project was important in avoiding fossil fuel consumption and therefore reducing GHG emissions. There were also riparian vegetation reforestation and conservation initiatives for the native fauna and flora. Economically the benefits were: contribution to local development by reducing the demand for imported energy; generating royalties from natural resources exploitation; acquiring equipment and services in the Brazilian market, stimulating the local economy and helping decentralize power generation in Brazil.

\section{Lages Bioenergética Ltda}

Lages Bioenergética Ltda is an independent power producer located in Southern Brazil. It was established in 2002 to build and operate a plant of electricity and steam co-generation, using wood waste as fuel. The Lages project sells $312 \mathrm{MW} / \mathrm{year}$ of electricity to the local power distribution company and to industrial customers and free consumers. The 25 tons/hour of steam produced in the plant is supplied to timber companies in the region. The Lages project is expected to reduce 220,439 tonnes of $\mathrm{CO}_{2}$ eq/year from the anaerobic decomposition of wood waste which comes from various timber companies (Lages Bioenergética Ltda, 2005).

The main barriers identified in the project were: high investment risk due to the pioneering nature of the project; difficult configuration of the supply chain for collecting wood waste; no incentives for local timber producers to use energy efficiently, given the abundance of wood waste. The greatest motivator for project implementation was identified as the opportunity for environmental improvement in the timber production through the deployment of a profitable business encouraged by the carbon market. The public funding of BNDES and a simplified system for granting environmental permits were also relevant for the project implementation (J. Minuzzo, personal communication, May 12, 2009).

As the technology for the development of this project is totally dominated in the Brazilian market and is widely used by the sugar and ethanol industry for co-generation of electricity by burning sugarcane bagasse, technology transfer was predominantly endogenous. Both the know-how and the equipment used by the project were mostly acquired in the national market. Its environmental-technological strategy is focused on external recycling of wood waste from the timber industry for generating electricity/steam. It does not prevent or reduce pollution generation (wood waste) at source (the timber industry). Therefore, it utilizes a kind of environmental technology between end-of-pipe and cleaner ones.

Socially, the project has generated employment and income, safer working conditions, professional training and medical and dental care. Environmentally, besides reducing GHG emissions, the project uses the ashes from 
burned wood waste as a fertilizer in local crops. Economically, the benefits were increasing local suppliers' capacity and creating a local wood waste spot market.

Vega Engenharia Ambiental S.A.

Vega's CDM project, implemented in northeastern Brazil, is one of the pioneers in GHG emission reductions through landfill biogas capture and flaring. The project provides a reduction of 872,375 tonnes of $\mathrm{CO}_{2}$ eq/year and produces 63,000 MW/year of electricity (Battre, 2004).

Even though it was not the first project of its nature approved in Brazil, this was the first one to fulfill the entire CDM project cycle, being officially registered as a CDM project by CIMGC in 2004. Thus, among the main barriers faced by Vega, there were certain difficulties concerning the pioneering nature of this project: They invested resources in hiring international consultants (ICF Consulting) to prepare the PDD; They faced the lack of institutional frameworks to regulate MDL projects in Brazil, such as the lack of clear rules for the nationalization of resources derived from carbon credit sales, and the impossibility to generate energy for sale, due to restrictions imposed by UNFCC's methodology, in order to comply with the project's additionality criteria. The great motivator for executing this project was the possibility of obtaining resources from the carbon credits for incremental technological changes in the landfill (M. Zulauf, personal communication, May 6, 2009).

In this project, there was little transfer of exogenous technology; only few equipment were imported from the USA. Vega used the resources from carbon credits to: improve the landfill technology in order to accelerate organic matter decomposition and increase biogas generation; and accelerate the development of a flex-fuel power generator. It should be noted, however, that the environmental-technological strategy was end-of-pipe since it naturally focused on waste treatment and not on preventing pollution at source.

Socially, the project's contributions to sustainable development were: professional training and creation of socio-environmental education projects for the community. Environmentally, the project helped by developing a flex-fuel generator and reducing GHG emissions. Among the economic benefits of the project were: increasing tax collection; purchasing equipment and services in the domestic market; contributing to the development of local markets; and making the transfer of technologies to other landfills possible. In general, it appears that the contribution of Vega's project to the sustainable development of its area was low because its technology was strictly end-of-pipe.

\section{NovaGerar}

NovaGerar is a joint venture between EcoSecurities, a finance management firm specialized in GHG mitigation issues and S.A. Paulista, a Brazilian engineering and construction company based in southeastern Brazil. This CDM project provides a reduction of 359,390 tonnes of $\mathrm{CO}_{2} \mathrm{eq} /$ year and generates 39,240 MW/year of electricity from the combustion of landfill biogas (Nova Gerar Eco Energia Ltda, 2004).

Its pioneering work - the first approved CDM project in Brazil—shares many similarities with Vega's, in particular regarding the main barrier faced: the lack of an institutional framework to regulate CDM in Brazil. The economic motivations were more compelling than the environmental objective of reducing GHG emissions: unlike Vega's, NovaGerar envisioned diversifying the company's activities by selling electricity produced from biogas burning (P. Braga, personal communication, July 2, 2009).

Regarding technological aspects, it was noted that the technology transfer was predominantly endogenous, 
similar to the Vega case. The environmental-technological strategy adopted was end-of-pipe as well, because it did not prevent pollution at source. However, at least the project used the urban waste power potential to generate and sell electricity to the public power distribution company, donating the surplus to surrounding communities. When compared to the Vega project, the contribution of NovaGerar to the sustainable development of its area of influence was greater, but still not outstanding. Among the project's social contributions professional training and employment and income generation can be highlighted. Environmentally, the project reduced GHG emissions and promoted selective waste collection and recycling. Economically, the most relevant benefits were: achieving power self-sufficiency; selling energy as an opportunity for diversifying the company's activities; purchasing equipment and services in the domestic market; and increasing tax revenue.

\section{Sadia}

Headquartered in southeastern Brazil, Sadia is one of the largest food companies in Latin America and one of the biggest exporters in Brazil. It employs 55 thousand people and relies on 10,000 poultry and pig farms, which are part of its supply chain for raw materials. Its CDM project aims to treat swine waste, using anaerobic biodigestors, and subsequently flare-burning GHGs generated, eliminating 591,418 tonnes of $\mathrm{CO}_{2}$ eq/year. (Instituto Sadia, 2008).

The main barrier to the implementation of such project is its uniqueness, which has resulted in a learning process for Sadia and also for the UNFCCC itself, which ended up framing the project in a new category: the Programmatic CDM, according to the approved methodologies from methane recovery in animal manure management systems. The shortage of local equipment suppliers for implementing the project according to the requirements defined in UNFCC's methodology was also a major barrier. The main motivation for this project, which received public funding through BNDES, was complying environmental legislation that required Sadia to reduce the negative environmental impacts of waste generation in its supply chain farms, decreasing water vector diseases, odors and bacteria, leading to life quality improvements (A. Luz-Sobrinho, personal communication, July 30, 2009).

Despite the scarcity of local equipment suppliers, there was little transfer of exogenous technologies. Predominantly, endogenous technology was developed by Sadia and national suppliers. As regards the environmental-technological strategy adopted, the project provides an end-of-pipe solution, treating swine waste anaerobically and reducing soil and groundwater contamination risks. The main social contribution from the project was transferring this technology to small integrated farms, which would not have had access to it without the participation of Sadia, due to high implementation costs. Thus, Sadia's project contributed to settle people in rural areas and trained its suppliers. Environmentally, the project contributed to GHG emissions mitigation and the reduction of the environmental impacts of a large production of swine manure. Economically, the highlights were: an increase in job creation and income generation in rural areas and the development of local equipment suppliers. Despite these benefits, Sadia's project contribution to sustainable development was low because the applied technology was exclusively end-of-pipe.

\section{Agrosuínos/AgCert}

Located in northeastern Brazil, the Agrosuínos is a small independent swine farm with 6,500 pigs. Similar to Sadia's, its CDM project provides a reduction of 14,163 tonnes of $\mathrm{CO}_{2}$ eq/year by installing anaerobic 
biodigestors and burning the biogas from swine manure treatment (Agcert, 2005; G. Costa, personal communication, July, 8, 2009).

The difficulties faced by this small farm in executing this project were minimized because AgCert, a now extinct consulting firm based in Ireland, specialized in swine manure treatment systems, was responsible for the entire CDM project cycle. Agrosuinos kept $10 \%$ of the revenue generated by the sale of carbon credits. While the main motivation for this small non-integrated swine producer was to comply with the environmental legislation, AgCert's main motivation was the profit it would get from receiving $90 \%$ of the revenue derived from the sale of carbon credits. It is important to note that until 2007, all swine manure treatment CDM projects approved in Brazil, with the exception of Sadia's, were developed by AgCert.

Technologically, exogenous transfer of technology was prevalent since the entire project cycle and technical assistance to Agrosuínos were performed by a subsidiary of AgCert in Canada, from where some equipment and know-how were imported. As in Sadia's project, the environmental-technological solution used was end-of-pipe, because it did not avoid pollution generation, but only treat this pollution. The project's environmental benefits include a reduction in GHG emissions and mitigation of the impacts caused by improper disposal of swine manure, combined with the generation of a biofertilizer, by-product of anaerobic degradation of this waste. Regarding social benefits, as in Sadia's project, technology was transferred to a small farm, which would otherwise not have been able to access such technology without the assistance of an external agent. Therefore, this project contributed to settling people in rural areas and to training workers of small independent swine farms. Economically it should be highlighted that: pig production capacity was increased by up to almost 100 times; employment and income in rural areas was increased; and tax revenue also increased. As in Sadia's project, despite all these benefits, from a triple bottom line perspective this project's contribution to sustainable development was low.

\section{FAFEN/Petrobras}

Petrobras is a Brazilian energy company that operates in several segments in national and international markets such as oil and gas, petrochemicals, fertilizers and ethanol. The CDM project, developed by the Petrobras nitrogen fertilizer plant (FAFEN), located in northeastern Brazil, aims to catalytically destroy $\mathrm{N}_{2} \mathrm{O}$ and reduce 57,366 tonnes of $\mathrm{CO}_{2}$ eq/year (FAFEN-BA, 2008).

There were no major barriers for this project's development other than: project approval delay by UNFCCC and some difficulties in importing the catalyst technology, which was developed by a German company. The main motivation for developing this project was reducing Petrobras's GHG emissions and thus contributing to the company's image in terms of environmental responsibility (E. Braga, personal communication, October 12, 2009).

Since the project consists of installing a catalytic reactor to destroy $\mathrm{N}_{2} \mathrm{O}$ generated at the fertilizer plant and not to decrease GHG production in the first place, the environmental-technologial strategy adopted was clearly end-of-pipe. In order to implement the project, there was both exogenous and endogenous technology transfer. For project design, an American consulting company, MGM International, was chosen to assist Petrobras in drafting the PDD. The engineering project and the specification/purchase of equipment other than the catalytic reactor bought from Germany were made by Petrobras in the domestic market. 
This project's contribution to the sustainable development of its area is low. There was no significant generation of employment or income. The only social contribution was training of few professionals to operate and maintain the project. Environmentally, the main contributions were GHG emissions reduction and the allocation of $5 \%$ of funds from the sale of carbon credits to promote environmental education projects in local communities. Economically, the main contributions were: improved corporate image of Petrobras; and better operational control of the fertilizer plant due to continuous monitoring of $\mathrm{N}_{2} \mathrm{O}$ generation.

\section{Comparative Analysis of Cases}

This section presents a comparative analysis of the ten cases based on the theoretical concepts and dimensions of the research analysis model (see Table 1): CDM project cycle; technology transfer and environmental technology; sustainable development and triple bottom line.

\section{CDM Project Cycle}

This subsection shows the results regarding the main barriers and motivations, the influence of public policies, and the role of stakeholders identified during the project cycles of the 10 CDM projects studied.

According to a comparative analysis, it can be observed that the main barriers identified were: long-term investment risks (seven projects) — due to high development costs and uncertainty about the future of the Kyoto Protocol after 2012 —and legal, institutional and bureaucratic issues (seven projects). As regards the latter, it was noted that the excessive bureaucracy in issuing environmental permits and the absence of a legal and institutional framework in Brazil with clear rules to regulate the resources derived from CERs sales were the major barriers that the Brazilian CDM project proponents had to overcome. Other barriers also mentioned were: the lack of equipment suppliers and local infrastructure (three projects); resistance from the local community and project development pioneering nature (three projects). In two projects studied (Agrosuínos/Agcert and FAFEN/Petrobras) no major barriers were faced. In Agrosuinos's case, AgCert itself covered the entire PDD approval cycle and provided all the infrastructure necessary for project implementation; in FAFEN's case, Petrobras carried out all the steps to import the catalyst, buy other equipment in the national market and also hire the international consultants to assist in the PDD preparation.

In six projects (Rosa dos Ventos, Água Doce, Erval Seco, Grupo Votorantim/UHEPC, Vega, and NovaGerar) the economic aspect-represented by the opportunity to diversify business and participate in the promising carbon market with profitability—was the main motivation for implementing CDM projects, leaving the environmental aspect as the main motivation in only two cases (Sadia and FAFEN/Petrobras). In the remaining two cases (Lages and Agrosuínos/Agcert) both aspects (economic and environmental) were equally important. In the Agrosuinos case, for example, while profitability was crucial for AgCert, the opportunity for small swine farmers to improve environmental performance and legislation compliance was identified as Agrosuinos' main motivation for accepting the AgCert project offer.

Reducing dependence on hydropower and to diversify the country's energy matrix was identified as a motivator in four projects. The existence of national public funding policies was identified as a motivation in two projects, especially for ones related to wind energy production (Rosa dos Ventos and Água Doce), due to the low interest that this sort of project attracts in Brazil.

Thus, both the national public funding policies—-from PROINFA and BNDES, and the Kyoto Protocol, as 
an instrument of international public policy, were important to implement some of the CDM projects studied. The role of stakeholders was considered a relevant aspect only for a few of the CDM projects studied, especially regarding the participation of members of civil organizations and local communities during the project approval cycle.

\section{Technology Transfer and Environmental Technology}

The results of this research regarding the types and forms of technology transfer and environmental technologies adopted by the $10 \mathrm{CDM}$ projects studied are summarized in this subsection.

As regards the technology transfer types, in only four CDM projects (Rosa dos Ventos, Água Doce, Agrosuínos/Agcert, FAFEN/Petrobras) the transfer was predominantly or partly exogenous, from an Annex I country to another non-Annex I country, as the Kyoto Protocol requires. In the remaining six projects (Erval Seco, Grupo Votorantim/UHEPC, Lages, Vega, NovaGerar, and Sadia), technology transfer occurred in a predominantly endogenous way, with importation of only little equipment. The acquisition/development of most of the know-how and equipment necessary for the implementation of these six projects was carried out in Brazil.

As for the types of environmental technologies adopted, it was observed that five CDM projects (Vega, NovaGerar, Sadia, Agrosuínos/Agcert and FAFEN/Petrobras) used end-of-pipe technologies, focused on the treatment of urban (landfills), animal (swine) waste and on catalytic destruction of $\mathrm{N}_{2} \mathrm{O}$ generated during fertilizer production. In one project (Lages), the adopted technology was according to LaGrega et al. (1994) a transition between end-of-pipe and cleaner technologies: the external recycling of biomass (wood waste) to generate electricity and steam. Therefore, the remaining four projects studied (Rosa dos Ventos, Água Doce, Erval Seco and Grupo Votorantim/UHEPC) were focused on pollution prevention and promoting cleaner technologies, contributing to the diversification (wind power) or maintenance (hydropower) of the Brazilian energy matrix based on renewable energy sources.

The explanation for these results may be linked to the information presented in Table 2, which shows that projects classified as end-of-pipe reduce GHG about 5.6 times more than projects that focus on the promotion of cleaner technologies. On the other hand, they generate about 6 times less energy than the latter. While the five projects related to hydropower and other renewables (wind and biomass) estimate a reduction of only 335,571 tonnes of $\mathrm{CO}_{2}$ eq/year and the generation of $622,015 \mathrm{MW} /$ year of energy, the other five projects related to the burning of biogas $\left(\mathrm{CH}_{4}\right)$ from the swine/urban waste treatment and the destruction of $\mathrm{N}_{2} \mathrm{O}$ estimate a reduction of 1,894,712 tonnes of $\mathrm{CO}_{2}$ eq/year and the generation of only 102,240 MW/year. Obtaining carbon credits is proportionately easier with end-of-pipe projects related to $\mathrm{CH}_{4}$ and $\mathrm{N}_{2} \mathrm{O}$ emissions control because they have GWP much greater than $\mathrm{CO}_{2}$ (see footnote 1) corroborating the view of Pearson (2007) that CDM projects that promote cleaner technologies do not have price differentiation proportional to higher implementation costs and also end up generating fewer carbon credits.

\section{Sustainable Development and Triple Bottom Line}

Finally, this subsection summarizes the results considering the social, environmental and economic components from triple bottom line sustainable development in all the ten CDM projects studied.

It can be observed that triple bottom line contribution to sustainable development existed in four CDM projects studied (Rosa dos Ventos, Água Doce, Erval Seco and Grupo Votorantim/UHEPC): those that used 
cleaner technologies for energy generation (wind and hydro power). In two projects (Lages and NovaGerar), there was average contribution to sustainable development- these projects produced energy through the external recycling of biomass or urban waste incineration, so they were classified as double bottom line as they covered two out of the three basic sustainable development components. In the remaining four (Vega, Agrosuínos/Agcert, Sadia and FAFEN/Petrobras) their contribution to sustainable development was considered low because their end-of-pipe urban or swine waste treatment technology without power generation and catalytic destruction of $\mathrm{N}_{2} \mathrm{O}$ only covered for one of the three basic sustainable development components, being classified as single bottom line.

In the projects with a single bottom line profile (low contribution to sustainable development), it was found that among the three components examined, the economic one was predominant: local markets development, tax revenue increase, employment and income generation and increased competitiveness. The environmental and social components had modest contributions, focused on the mitigation of GHG emissions, training of professionals and settling workers in rural areas. In projects with an average contribution (double bottom line profile), there is a predominance of economic and environmental components, but not of the social component. In triple bottom line projects there was a better balance between the social, environmental and economic contributions.

\section{Conclusion}

This paper has analyzed the contribution of CDM projects to cleaner technology generation and the promotion of sustainable development in Brazil. For this, 10 cases that represent the Brazilian context were selected: five renewable energy production projects and five other on swine/urban waste treatment and $\mathrm{N}_{2} \mathrm{O}$ destruction. A multiple-case study method was chosen and a data triangulation technique was used to collect the data from the 10 selected projects. The analysis and discussion of results was made based on a model built upon the following concepts: CDM project cycle, technology transfer, environmental technology and sustainable development.

The results indicate that more than half (six) of the studied CDM projects used technologies that were either end-of-pipe or somewhere in between cleaner and end-of-pipe, and also had single or double bottom line profiles, showing more benefits on the economic component than on the social and environmental components of sustainable development. In two thirds of these projects, the economic motivation, represented by the opportunity to make a profit by entering the carbon market was more important than the socio-environmental motivation for joining CDM.

Projects that promoted cleaner technologies with a triple bottom line profile represent only four out of the 10 CDM projects studied. In two of these triple bottom line projects, which specifically focused on wind energy production, a greatest number of CDM project implementation barriers were found: long-term investment risks and legal, institutional and bureaucratic issues. In these projects it was also noted that technology transfer was in part exogenous, showing that Brazil lacks domestic suppliers for wind power equipment and still has not mastered this power making technology. In the majority (six) of the CDM projects studied though, technology transfer occurred in a predominantly endogenous fashion, with most of the know-how and equipment acquisition/development happening in Brazil. 
It should be also highlighted that national public funding policies played an important role in aiding the implementation of cleaner technology CDM projects in Brazil and also in reducing the degree of exogenous technology transfer, as seen in PROINFA's funding requirement to have at least $60 \%$ of equipment and know-how acquired or developed domestically. The influence of other stakeholders, such as local communities, during the CDM project cycle was considered decisive only for some of the projects studied. Most of the projects were implemented with minimal influence from local communities.

In conclusion, this paper defends that, although the Brazilian CDM projects have shown high levels of endogenous technology transfer, in general, they have been responsible for only a modest to incipient contribution to the generation of cleaner technologies and a triple bottom line sustainable development. This may be linked to the fact that CDM projects that use end-of-pipe technology are usually more financially attractive than their cleaner technology-based counterparts, due to lower investment costs, low technology risks and proportionally bigger carbon credits gains. This may explain why so far CDM has failed, as a global climate governance mechanism, for achieving sustainable development and stimulating cleaner technologies through an economic instrument of environmental management-the carbon market. Thus, considering that the Kyoto Protocol establishes the need for technological cooperation between the participating countries of CDM projects through the exogenous transfer of environmentally sound technologies for sustainable development and based on the study of the Brazilian experience, this paper argues that it is necessary, in the post-Kyoto period, for CDM to better foster strong joint development of cleaner technologies among host and donor countries. Only exogenously transferring environmentally sound technologies is not sufficient to achieve clean development, as they could be too much focused on end-of-pipe strategies for treatment/remediation of GHG emissions, rather than on technologies for effective emission prevention/reduction.

Finally, it is recommended that future studies compare the Brazilian experience with that of the other two main CDM host countries in the world-India and China. This will further evaluate the contribution of this instrument of global clima governance for the generation of cleaner technologies for sustainable development, considering technology types, the amount of carbon credits obtained and the investment's return rate.

\section{References}

Abranches, S. (2009). COP-15: o acordo possível. Retrieved from http://www.ecopolitica.com.br

Agcert do Brasil Soluções Ambientais Ltda. (2005). Documento de Concepção de Projeto. Retrieved from http://www.mct.gov.br/index.php/content/view/58276.html

Agência de Notícias dos Direitos da Infância (ANDI). (2009). COP 15: As posições dos principais países. Retrieved from http://www.mudancasclimaticas.andi.org.br/cop15/node/4.

Água Doce. (2006). Documento de Concepção de Projeto. Retrieved from http://www.mct.gov.br/index.php/content/view/58223.html

Andrade, J. C. S., Silva-Junior, A. C., Napravnik Filho, L., Telesforo, A. C., \& Ventura, A. C. (2009). Clean development mechanism (cdm) in brazil: an instrument for technology transfer and the promotion of cleaner technologies? Paper presented at the International Workshop Advances in Cleaner Production, São Paulo, Brazil.

Bahia Transferencia e Tratamento de Residuos S.A. (BATTRE). (2004). Documento de Concepção de Projeto. Retrieved from http://www.mct.gov.br/index.php/content/view/58108.html

Bardin, L. (1977). Análise de Conteúdo. São Paulo: Persona.

Blackman A. (1999). The economics of technology diffusion: Implications for climate policy in developing countries. Working paper, 99-42, Washington, D.C.: Resources for the future. 
Bozeman, B. (2000). Technology transfer and public policy: A review of research and theory. Research Policy, 29, 627-655.

Brasil. (2004). Protocolo de Quioto e legislação correlata. Coleção Ambiental (Vol. 3). Brasília: Senado Federal.

Brasil. (2009). Política Nacional sobre Mudança do Clima. Retrieved from http://www.planalto.gov.br/ccivil_03/projetos/PL/2008/msg345-080605.htm

Brundtland Commission. (1987). Our common future: Report by the World Commission on Environment and Development. Oxford, England: Oxford University Press.

BT Geradora de Energia Elétrica S.A. (PCH). (2005). Documento de Concepção de Projeto. Retrieved from http://www.mct.gov.br/index.php/content/view/58177.html

Comissão Interministerial Sobre Mudança Global do Clima (CIMGC). (2003). Resolução nº1. Brasília, Brasil.

Dechezleprêtre, A., Glachant, M., \& Méniére, Y. (2009). Technology transfer by CDM projects: A comparasion of Brazil, China, India e Mexico. Energy Policy, 37, 703-711.

Elkington, J. (1994). Towards the sustainable corporation. California Management Review, 36(2), 90-100.

Ellis, J., Winkler, H., Corfee-Morlot, J., \& Cagnon-Lebrun, F. (2007). CDM: Taking stock and looking forward. Energy Policy, 35(1), 15-28.

Esty, D. C., \& Ivanova, M. (Org.). (2002). Global environmental governance: Options and opportunities. New Haven, C.T.: Yale School of Forestry \& Environmental Studies.

Esty, D. C., \& Winston, A. S. (2006). Green to gold: How smart companies use environmental strategy to innovate, create value, and build competitive advantage. New Haven and London: Yale University Press.

Fábrica de Fertilizantes Nitrogenados da Bahia (FAFEN-BA). (2008). Documento de Concepção de Projeto. Retrieved from http://www.mct.gov.br/index.php/content/view/300411.html

Furrer, B. (2009). Strategic change: Hybrids of simbolic and substantive action? The case of banks' climate strategies. Paper presented at the Academy of Management Annual Meeting, Chicago.

Goldemberg, J. (2005). O Caminho até Joanesburgo. In A. Trigueiro (Ed.), Meio ambiente no século 21 (pp. 34-50). Rio de Janeiro: Sextante.

Grau-Neto, W. (2007). O Protocolo de Quioto e o Mecanismo de Desenvolvimento Limpo-MDL: uma análise crítica do instituto. São Paulo: Fiúza.

Grupo Votorantim. (2006). Documento de Concepção de Projeto. Retrieved from http://www.mct.gov.br/index.php/content/view/58230.html

Guimarães, R. P. (2001). A Ética da Sustentabilidade e a Formulação de Políticas de Desenvolvimento. In G. Viana (Ed.), O Desafio da Sustantabilidade: Um Debate Socioambiental no Brasil (pp. 43-71). São Paulo: Fundação Perseu Abramo.

Haigh, N. (2009). Strategizing for physical climate change? Sensemaking and strategies in response to climate impacts. Paper presented at the Academy of Management Annual Meeting, Chicago.

Instituto Sadia. (2008). Documento de Concepção de Projeto. Retrieved from http://www.mct.gov.br/index.php/content/view/58268.html

Kanai, K. (2008). A transferência de conhecimento tecnológico: análise do caso-“Curso de Treinamento nos Terceiros Países”. Faculdade de Educação, Dissertação de mestrado não-publicada, Universidade Estadual de Campinas, Campinas, São Paulo, Brasil.

Kiperstok, A. (Coord.). (2003). Inovação e meio ambiente: elementos para o desenvolvimento sustentável na Bahia. Salvador: Centro de Recursos Ambientais.

Kopinak, J. K. (1999). The use of triangulation in a study of refugee well-beings. Quality \& Quantity, 33, 169-183.

Lages Bioenergética Ltda. (2005). Documento de Concepção de Projeto. Retrieved from http://www.mct.gov.br/index.php/content/view/58192.html

LaGrega, M. D., Buckingham, P. L., \& Evans, J. C. (1994). Hazardous waste management. New York: McGraw-Hill.

Le Prestre, P. (2005). Protection de l'environnement et relations internationales: les défis de l'écopolitique mondiale. Paris: Armand Colin.

Lenzi, C. L. (2006). Sociologia ambiental: risco e sustentabilidade na modernidade. São Paulo: Edusc.

Lopes, I. V. (Coord.). (2002). O Mecanismo de Desenvolvimento Limpo-MDL: Guia de Orientação. Rio de Janeiro: Fundação Getúlio Vargas.

Milani, C. R. S., \& Keraghel, C. (2007). The international agenda for sustainable development: International contestatory movements. In S. Thoyer, \& B. Martimort (Eds.), Participation for sustainability in trade (pp. 93-109). Londres: Ashgate. 
Ministério da Ciência e Tecnologia (MCT). (2008). Manual para Submissão de Atividades de Projeto no Âmbito do MDL. Versão 2. Brasília.

Ministério da Ciência e Tecnologia (MCT). (2011). Status atual das atividades de projeto no âmbito do Mecanismo de Desenvolvimento Limpo (MDL) no Brasil $e$ no Mundo. Retrieved from http://www.mct.gov.br/index.php/content/view/30317.html

Nova Gerar Eco Energia Ltda. (2004). Documento de Concepção de Projeto. Retrieved from http://www.mct.gov.br/index.php/content/view/58107.html

Pearson, B. (2007). Market failure: why the clean development mechanism won't promote clean development. Journal of Cleaner Production, 15, 247-252.

Quivy, R., \& Campenhoudt, L. (1998). Manual de investigação em Ciências Sociais. Lisboa: Gradiva.

Radosevic, S. (1999). International technology transfer and catch-up in economic development. Massachusetts: Edward Elgar.

Rosa dos Ventos. (2007). Documento de Concepção de Projeto. Retrieved from http://www.mct.gov.br/index.php/content/view/58227.html

Rosemberg, N. (2006). Por dentro da caixa-preta: tecnologia e economia. Campinas: UNICAMP.

Russo, A., \& Pogutz, S. (2009). Eco-efficiency vs. Eco-effectiveness: Exploring the link between GHG emissions and firm performance. Paper presented at the Academy of Management Annual Meeting, Chicago.

Sachs, I. (1993). Estratégias de Transição para o Século XXI. São Paulo: Nobel.

Schneider, M., Holzer, A., \& Hoffman, V. H. (2008). Understanding the CDM’s contribution to technology transfer. Energy Policy, 36(8), 2930-2938.

Seiffert, M. E. B. (2009). Mercado de Carbono e Protocolo de Quioto: oportunidades de negócio na busca da sustentabilidade. São Paulo: Atlas.

Seres, S. (2007). Analysis of Technology Transfer in CDM Projects. Retrieved from http://cdm.unfccc.int/Reference/Reports/TTreport/report1207.pdf

Silva-Junior, A. C., Napravnik-Filho, L., \& Andrade, J. C. S. (2009). Brazilian Clean Development Mechanism (CDM) Projects: putting up the technology against the wall. Paper presented at the 8th World Congress of Chemical Engineering, Montreal, Canada.

Soares-Neto, P. B. (2004). Governança e o Eco-comprometimento promovendo Desenvolvimento Sustentável a partir da Gestão de Recursos Hídricos: o caso da Aracruz/ Unidade Guaíba e seus stakeholders. Retrieved from http://volpi.ea.ufrgs.br/teses_e_dissertacoes/td/001319.pdf

Telesforo, A. C., \& Loiola, E. (2009). Contribuição das Políticas Públicas Ambientais Brasileiras como Incentivadora de Projetos de Mecanismo de Desenvolvimento Limpo (MDL) na Área de Energia no Brasil. Artigo apresentado no Encontro Nacional de Gestão Empresarial e Meio Ambiente (ENGEMA), Fortaleza, Ceará, Brasil.

Tigre, P. B. (2006). Gestão da Inovação: a economia da tecnologia do Brasil. Rio de Janeiro: Elsevier.

United Nations Framework Convention on Climate Change (UNFCCC). (2011). CDM Statistics. Retrieved from http://cdm.unfccc.int/Statistics/index.html

Vela, J. A. A., \& Ferreira, E. (2005). Vantagem Competitiva do Brasil nos Projetos de MDL. Artigo apresentado no Encontro Nacional de Gestão Empresarial e Meio Ambiente (ENGEMA), Rio de Janeiro, Brasil.

Ventura, A. C. (2008). Mecanismo de Desenvolvimento Limpo (MDL): uma análise da regulação de conflitos socioambientais do Projeto Plantar. Dissertação de mestrado não-publicada. Escola de Administração, Universidade Federal da Bahia, Salvador, Bahia, Brasil.

Wilkins, G. (2002). Technology transfer for renewable energy overcoming barriers in developing countries. London: Earthscan.

World Business Council for Sustainable Development (WBCSD). (2006). Eco-eficiência: criar mais valor com menos impacto. Retrieved from http://www.wbscd.org

Yin, R. K. (2001). Estudo de Caso: planejamento e métodos (2nd ed.). Porto Alegre: Bookman.

Zhao, L., \& Reisman, A. (1992). Toward meta research on technology transfer. Engineering Management, 39, 13-21. 